\title{
KARAKTERISTIK MUTU SAMBAL LEMEA DENGAN VARIASI WAKTU FERMENTASI DAN JENIS IKAN
}

\section{QUALITY CHARACTERISTICS OF "SAMBAL LEMEA" WITH FERMENTATION TIME AND TYPE OF FISH}

\author{
Alan Oktarianto ${ }^{1)}$, Lina Widawati ${ }^{2)}$ \\ 1) Program Studi Teknologi Pertanian, Fakultas Pertanian, Universitas Dehasen Bengkulu \\ ${ }^{2)}$ Program Studi Teknologi Pangan, Fakultas Pertanian, Universitas Dehasen Bengkulu \\ Email : lina84id@gmail.com
}

\begin{abstract}
ABSTRAK
Lemea adalah makanan setengah jadi hasil proses fermentasi yang terbuat dari rebung yang dipotong dadu kecil-kecil dan dicampur ikan. Fermentasi yang dilakukan biasanya selama 3, 5 dan 7 hari. Lemea biasanya diolah lagi menjadi sambal lemea. Telah dilakukan penelitian dengan tujuan mengkarakterisasi pengaruh waktu fermentasi dan jenis ikan terhadap sifat fisik, kimia dan organoleptik sambal lemea dan mengkarakterisasi waktu fermentasi dan jenis ikan yang tepat dalam pembuatan sambal lemea. Metode dalam penelitian ini yaitu proses pembuatan lemea dan sambal lemea dengan perlakuan waktu fermentasi 72 jam, 120 jam dan 168 jam dan penambahan ikan air tawar (mujair) 500 gr dan ikan laut (manyung) 500 gr. Analisis pada penelitian ini meliputi analisis pH, TPC (Total Plate Count) dan sifat organoleptik.

Analisis pH lemea dengan perlakuan ikan air tawar (ikan mujair) dan ikan laut (ikan manyung) adalah berbeda nyata, $\mathrm{pH}$ tertinggi adalah $\mathrm{pH}$ yang terdapat pada perlakuan jenis ikan laut (ikan manyung) dengan waktu fermentasi 72 jam yaitu sebesar 7.566. Sedangkan $\mathrm{pH}$ terendah adalah perlakuan dengan lama fermentasi 168 jam yaitu sebesar 6.567 yang terdapat pada jenis ikan air tawar. TPC tertinggi adalah TPC yang terdapat pada perlakuan jenis ikan laut (ikan manyung) dengan waktu fermentasi 168 jam. Sedangkan TPC terendah adalah perlakuan dengan lama fermentasi 72 jam yaitu sebesar 1,200 baik pada jenis ikan air tawar ataupun ikan laut. Hasil analisa organoleptik warna sambal lemea yang paling disukai adalah sambal lemea dengan jenis ikan laut (manyung) dengan waktu fermentasi 168 jam. Hasil analisa organoleptik rasa sambal lemea yang paling disukai adalah sambal lemea dengan jenis ikan laut (manyung) dengan waktu fermentasi 168 jam. Hasil analisa organoleptik aroma sambal lemea yang paling disukai adalah sambal lemea dengan jenis ikan laut (manyung) dengan waktu fermentasi 168 jam
\end{abstract}

Kata Kunci: lemea, fermentasi, ikan

\section{ABSTRACT}

Lemea is a semi-finished food fermentation process results which are made of bamboo shoots are cut into small dice and mixed fish. Fermentation is done usually for 3, 5 and 7 days. Lemea usually processed again into sambal Lemea. Has conducted research with the aim to characterize the effect of fermentation and the type of fish to the physical, chemical 
and organoleptic sambal lemea and characterize the fermentation time and the right kind of fish sauce in the making lemea. The method in this research is the process of making lemea and sambal lemea treatment with fermentation time of 72 hours, 120 hours and 168 hours and the addition of fresh water fish (tilapia) $500 \mathrm{gr}$ and seafood ("manyung") $500 \mathrm{gr}$. The analysis in this study includes analysis of pH, TPC (Total Plate Count) and organoleptic properties.

Lemea pH analysis with the treatment of freshwater fish (tilapia fish) and sea fish (manyung fish) are significantly different, the highest $\mathrm{pH}$ is $\mathrm{pH}$ contained in the treatment of sea fish species (manyung fish) fermentation time of 72 hours is equal to 7566 . While the lowest $\mathrm{pH}$ is treated with the fermentation time of 168 hours in the amount of 6567 found in freshwater fish species. The highest TPC is contained in the treatment of sea fish species (manyung fish) fermentation time of 168 hours. While the lowest TPC is treated with a fermentation time of 72 hours in the amount of 1,200 both in freshwater fish or sea fish species. The results of the organoleptic analysis of chilli colour most favored entry is "sambal lemea" with sea fish species ("manyung") fermentation time of 168 hours. Results of analysis of organoleptic "sambal lemea" most preferred condiment is "sambal lemea" with sea fish species ("manyung") fermentation time of 168 hours. The results of the organoleptic analysis of flavour "sambal lemea" most preferred condiment is "sambal lemea" with sea fish species ("manyung") fermentation time of 168 hours

Keywords: lemea, fermentation, fish

\section{PENDAHULUAN}

Makanan tradisional merupakan makanan yang dikonsumsi oleh golongan etnik dan wilayah yang spesifik (Hadisantoso, 1993). Makanan tradisional diolah berdasarkan resep secara turuntemurun, bahan yang digunakan berasal dari daerah setempat, dan makanan yang dihasilkan juga sesuai dengan selera masyarakat setempat. Salah satu makanan tradisional Provinsi Bengkulu yang berbasis ikan adalah lemea, yang merupakan makanan daerah suku Rejang (Susanti, 2011).

Lemea adalah rebung hasil proses fermentasi yang terbuat dari rebung yang dipotong dadu kecil-kecil dan dicampur ikan. Aroma lemea sangat khas, yang berasal dari fermentasi ikan yang dicampur dengan rebung muda. Rebung yang sering digunakan untuk pembuatan lemea yaitu rebung betung (Denrocalamus asper) dan rebung Mayan (Gigantocioa robusta kurz). Rebung betung berwarna merah cokelat dan Subang (ujung kelopak) pada ujung rebung berwarna ungu. Setelah dicincang rebung yang dicampur dengan ikan tersebut disimpan atau difermentasikan (Sustrianti, 2011).

Perubahan selama fermentasi sangat berperan penting dalam proses pembuatan lemea. Tanpa adanya proses fermentasi maka campuran rebung dan 
ikan tidak akan menjadi lemea. Fermentasi merupakan proses perombakan makromolekul (karbohidrat dan protein) tanpa memerlukan oksigen atau dapat pula disebut respirasi anaerob. Teknologi fermentasi merupakan suatu cara yang dapat memperbaiki nilai gizi bahan makanan menjadi makanan yang berkualitas baik karena rasa, aroma, tekstur, daya cerna dan daya simpannya lebih baik dari bahan asalnya (Kholis 2010, dalam Suciati, 2012). Lemea dapat diolah menjadi berbagai jenis produk olahan seperti sambal lemea dan saos lemea (Sefti, 2015).

Fermentasi yang terus berlangsung setelah tahap optimum harus segera diambil, karena jika lemea tidak segera diambil dapat meningkatkan tingkat keasaman lemea dan terjadinya penyimpangan mutu lemea seperti menurunnya nilai gizi yang terkandung dalam lemea. Ada 2 substansi penting membuat lemea yaitu komposisi bahan baku berupa rebung dan ikan, hasil penelitian Dewi (2012) menunjukkan bahwa lama fermentasi memberikan pengaruh nyata terhadap sifat fisik, kimia dan jumlah koloni mikroba dan organoleptik pada lemea. Lama fermentasi menunjukkan penurunan keasaman sampai hari ke-3, peningkatan pada hari ke-7 dan menunjukkan nilai yang hampir konstan sampai hari ke 15. Pada sifat organoleptik lemea yang paling di sukai oleh konsumen adalah lemea dengan waktu fermentasi 15 hari. Kemudian hasil penelitian (Surna, 2011) dengan menggunakan berbagai macam jenis ikan yang digunakan dalam campuran lemea, menghasilkan tingkatan kesukaan pada lama fermentasi hari ke enam sampai ke tujuh dengan menggunakan bahan baku rebung dan ikan manyung. Berdasarkan uraian diatas dilakukan penelitian untuk mengkaji pengaruh waktu fermentasi dan jenis ikan terhadap mutu sambal lemea.

\section{METODE PENELITIAN}

\section{Alat dan Bahan}

Alat-alat yang digunakan dalam penelitian ini antara lain: pisau, panci, wajan, baskom, pengaduk besi, sendok, nampan, saringan, kompor, dan alat analisis.

Sedangkan bahan yang digunakan dalam penelitian ini adalah rebung dari bambu betung, air bersih, ikan mujair (Oreochromis mossambicus), ikan manyung (Arius thalassinus), serai, cabai, garam, bawang merah, dan bawang putih.

\section{Prosedur Penelitian}

Rebung dibersihkan dari kotorannya dan dicuci lalu dipotongpotong atau diiris kecil kecil dan dicincang (beda dengan sayur rebung, irisan potangannya lebih kecil dari irisan 
potongan sayur rebung yaitu $\pm 5 \times 0,5$ )

Ikan direbus, dan $200 \mathrm{ml}$ air rebusannya di masukkan ke dalam baskom. Setelah itu $1 \mathrm{~kg}$ irisan rebung juga dimasukkan ke dalam baskom dan tambahkan dengan 500 gr ikan (variasi perlakuan ikan mujair (Oreochromis mossambicus) dan ikan manyung (Arius thalassinus)) yang telah direbus beserta $200 \mathrm{ml}$ air rebusan ikan tersebut. Lalu difermentasikan (kondisi anaerob) dengan variasi waktu fermentasi (72, 120 dan 168 jam) Setelah fermentasi, lemea siap untuk diolah menjadi masakan lemea. Kemudian dilakukan proses pengolahan sambal lemea, dengan cara lemea yang telah difermentasi selama 72 jam, 120 jam dan 168 jam dimasukkan dalam wajan dan ditambahkan $200 \mathrm{ml}$ air. Dicampurkan 100 gr cabe dan 10 gr garam, 5 gr bawang merah, 3 gr bawang putih dan 5 gr serai ke dalam lemea lalu dimasak pada suhu $100^{\circ} \mathrm{C}$ selama 15 menit. Kemudian lemea yang telah dicampur dengan bahan rempah diaduk selama 15 menit. Setelah mengental kemudian diangkat dan setelah hilang uapnya dimasukkan ke dalam wadah yang sudah disediakan. Kemudian dianalisis tingkat keasaman, TPC dan organoleptik.

\section{Metode Penelitian}

Perlakuan yang diberikan adalah lama fermentasi dan jenis ikan. Rancangan percobaan yang digunakan adalah rancangan acak lengkap (RAL). Perlakuan yang diberikan adalah lama fermentasi 3 taraf dan jumlah ikan 2 taraf. Rancangan percobaan sebagai berikut:

1. Faktor waktu fermentasi (W)

$\mathrm{W} 1$ = Waktu fermentasi 72 jam

$\mathrm{W} 2=$ Waktu fermentasi 120 jam

W3 = Waktu fermentasi 168 jam

2. Jenis ikan $(\mathrm{J})$

$\mathrm{J} 1$ = Ikan tawar (ikan mujair)

J2 = Ikan laut (ikan manyung)

\section{Analisis Penelitian}

\section{Uji Sifat Kimia dan Mikrobiologis}

Uji sifat kimia dilakukan untuk mengetahui apakah terjadi perubahan $\mathrm{pH}$ dan TPC (Total Plate Count) pada lemea.

\section{Uji Organoleptik}

Uji organoleptik dilakukan untuk mengetahui tingkat penerimaan panelis terhadap lemea yang dihasilkan. Panelis yang digunakan adalah panelis agak terlatih terdiri dari 20 orang dari panelis yang familier dengan lemea.

\section{HASIL DAN PEMBAHASAN \\ pH (Derajat Keasaman) Lemea}

Tujuan analisis $\mathrm{pH}$ (derajat keasaman) adalah untuk menyatakan tingkat keasaman atau kebasaan yang dimiliki oleh bahan pangan. Hasil rerata analisis $\mathrm{pH}$ (derajat keasaman) lemea dengan perlakuan jenis ikan air tawar (ikan mujair) dan ikan laut (ikan 
manyung) dengan waktu fermentasi 72 jam, 120 jam dan 168 jam dapat dilihat pada Tabel 1.

Pada tabel 1. menjelaskan rerata analisis $\mathrm{pH}$ lemea dengan perlakuan ikan air tawar (ikan mujair) adalah berbeda nyata, rerata $\mathrm{pH}$ pada ikan laut (ikan manyung) juga menunjukkan perbedaan yang nyata terhadap perlakuan waktu fermentasi 72, 120 dan 168 jam pada taraf signifikan $5 \%$. Rerata penilaian terhadap nilai $\mathrm{pH}$ lemea pada ikan air tawar (ikan mujair) berkisar antara 6.567 hingga 7.033 dan pada jenis ikan laut (ikan manyung) berkisar antara 7.133 hingga 7.566.

Rerata penilaian terhadap nilai $\mathrm{pH}$ lemea dengan perlakuan jenis ikan air tawar (ikan mujair) dengan waktu fermentasi 72 jam adalah sebesar 7.033 dan pada waktu fermentasi 120 jam adalah sebesar 6.733 dan pada waktu fermentasi 168 jam adalah sebesar 6.567. Rerata penilaian terhadap nilai $\mathrm{pH}$ lemea dengan perlakuan jenis ikan laut (manyung) dengan waktu fermentasi selama 72 jam adalah sebesar 7.566, sedangkan pada waktu 120 jam adalah sebesar 7.200 dan perlakuan jenis ikan laut dengan waktu fermentasi selama 168 jam adalah sebesar 7.33.

Berdasarkan tabel $1 \mathrm{pH}$ tertinggi adalah $\mathrm{pH}$ yang terdapat pada perlakuan jenis ikan laut (ikan manyung) dengan waktu fermentasi 72 jam yaitu sebesar 7.566. Sedangkan $\mathrm{pH}$ terendah adalah perlakuan dengan lama fermentasi 168 jam yaitu sebesar 6.567 yang terdapat pada jenis ikan air tawar. Perlakuan waktu fermentasi berpengaruh terhadap derajat keasamaan pada lemea. Semakin lama waktu fermentasi maka semakin menurun nilai $\mathrm{pH}$ tersebut, artinya semakin lama fermentasi maka lemea menjadi lebih asam. Hal ini menunjukkan bahwa terjadinya penguraian bahan pada proses pembuatan lemea oleh mikroba sehingga $\mathrm{pH}$ menjadi semakin menurun. Penurunan $\mathrm{pH}$ disebabkan oleh adanya aktivitas fermentasi, yang mengubah karbohidrat dan gula dalam bahan makanan menjadi asam. Mikroorganisme yang berperan dalam penurunan $\mathrm{pH}$ adalah bakteri asam laktat (Hayati, 2009).

Berdasarkan hasil penelitian dapat dilihat $\mathrm{pH}$ dengan perlakuan jenis ikan air tawar (ikan mujair) lebih rendah dibanding $\mathrm{pH}$ dengan perlakuan ikan laut (ikan manyung). Hal ini disebabkan kadar air pada jenis ikan air tawar (ikan mujair) lebih rendah di bandingkan kadar air ikan laut (ikan manyung). 
Tabel 1. Hasil Analisis pH Lemea

\begin{tabular}{|c|c|c|}
\hline $\begin{array}{c}\text { Waktu Fermentasi } \\
(\text { Jam) }\end{array}$ & \multicolumn{2}{|c|}{ Jenis Ikan } \\
\cline { 2 - 3 } & $\begin{array}{c}\text { Ikan Air Tawar } \\
\text { (Ikan Mujair) }\end{array}$ & $\begin{array}{c}\text { Ikan Laut } \\
\text { (Ikan Manyung) }\end{array}$ \\
\hline $\mathbf{7 2}$ & $7.033^{\mathrm{c}}$ & $7.566^{\mathrm{a}}$ \\
\hline $\mathbf{1 2 0}$ & $6.733^{\mathrm{d}}$ & $7.200^{\mathrm{b}}$ \\
\hline $\mathbf{1 6 8}$ & $6.567^{\mathrm{e}}$ & $7.133^{\mathrm{b}}$ \\
\hline
\end{tabular}

Ket : Angka yang diikuti oleh kode huruf yang berbeda menunjukkan adanya perbedaan yang nyata pada taraf signifikansi 5\%, (pada kolom yang sama)

Menurut Litbang (2012) untuk kadar air ikan air tawar (ikan mujair) adalah 75,4 \% dan ikan laut (ikan manyung) adalah 78,2\%. Semakin rendah kadar air yang terkandung dalam suatu bahan maka semakin asam bahan pangan tersebut, dan sebaliknya. Begitu juga dengan protein yang terkandung pada jenis ikan air tawar (ikan mujair) lebih rendah di bandingkan protein ikan laut (ikan manyung), yaitu masing-masing untuk protein ikan air tawar (ikan mujair) adalah 18.2 gr dan ikan laut (ikan manyung) adalah 21,4 gr. Semakin rendah protein yang terkadung dalam suatu bahan maka akan semakin cepat terjadi denaturasi protein. Akibat denuturasi protein, maka terjadi penurunan kelarutan protein, daya ikat air hilang sehingga terjadi penurunan $\mathrm{pH}$. Menurut Hayati, (2009), menyatakan bahwa $\mathrm{pH}$ yang mengalami penurunan dimana $\mathrm{pH}$ akan semakin asam. Pada saat terjadi penurunan $\mathrm{pH}$ dalam fermentasi, mikroorganisme yang terdapat pada bahan mengalami pertumbuhan karena pada saat $\mathrm{pH}$ menurun akan terbentuk asam-asam organik yang digunakan mikroba sebagai nutrisi untuk pertumbuhannya sehingga populasi mikroba di dalam bahan meningkat.

\section{Analisis TPC (Total Plat Count) Lemea}

Analisis TPC (Total Plate Count) lemea berfungsi untuk menggambarkan bahwa terdapat aktivitas dan kondisi pertumbuhan masing-masing mikroba yang berperan pada tiap perlakuan sampel lemea. Semakin banyak nutrisi yang tersedia pada lemea maka, akan semakin meningkatnya pertumbuhan mikroorganisme untuk tumbuh. Proses fermentasi mikroba akan menghasilkan enzim yang akan mendegradasi senyawasenyawa komlek menjadi lebih sederhana, dan mikroba juga akan mensintesis protein yang merupakan proses protein enrichment. 
Hasil rerata analisis TPC (Total Plate Count) lemea dengan perlakuan jenis ikan air tawar (ikan mujair) dan ikan laut (ikan manyung) dengan waktu fermentasi 72, 120 dan 168 jam dapat dilihat pada tabel 2 .

Tabel 2. menjelaskan rerata analisis TPC lemea dengan perlakuan ikan air tawar (ikan mujair) adalah berbeda nyata, rerata TPC pada ikan laut (ikan manyung) juga menunjukkan perbedaan yang nyata terhadap perlakuan waktu fermentasi 72 jam, 120 jam dan 168 jam pada taraf signifikan 5\%. Rerata penilaian terhadap nilai TPC lemea pada ikan air tawar (ikan mujair) berkisar antara 1,200 koloni/g hingga 2,900 koloni/g dan pada jenis ikan laut (ikan manyung) berkisar antara 1,200 koloni/g hingga 4,700 koloni/g. Berdasarkan data diatas dapat diketahui bahwa waktu fermentasi berpengaruh terhadap kandungan mikroorganisme lemea hingga waktu fermentasi 168 jam, dimana pada perlakuan waktu fermentasi 72 jam sudah timbul bakteri, sedangkan pada perlakuan waktu fermentasi 120 jam jumlah mikroorganime meningkat menjadi 2,500 koloni/g. Hingga waktu fermentasi 168 jam dari hasil analisis terhadap TPC lemea menunjukkan jumlah mikroorganisme terbesar baik pada ikan air tawar (ikan mujair) maupun ikan laut (ikan manyung) masing-masing yaitu 2,900 koloni/g dan 4,700 koloni/g.

Rerata penilaian terhadap nilai TPC lemea dengan perlakuan jenis ikan air tawar (ikan mujair) dengan waktu fermentasi 72 jam adalah sebesar 1,200 koloni/g dan pada waktu fermentasi 120 jam adalah sebesar 1,500 koloni/g dan pada waktu fermentasi 168 jam adalah sebesar 2,900 koloni/g. Rerata penilaian terhadap nilai TPC lemea dengan perlakuan jenis ikan laut (manyung) dengan waktu fermentasi selama 72 jam adalah sebesar $1.200 \mathrm{koloni} / \mathrm{g}$, sedangkan pada waktu 120 jam adalah sebesar 1,800 koloni/g dan perlakuan jenis ikan laut dengan waktu fermentasi selama 168 jam adalah sebesar 4,700 koloni/g.

Berdasarkan tabel 2 TPC tertinggi adalah TPC yang terdapat pada perlakuan jenis ikan laut (ikan manyung) dengan waktu fermentasi 168 jam yaitu sebesar 4,700 koloni/g. Sedangkan TPC terendah adalah perlakuan dengan lama fermentasi 72 jam yaitu sebesar 1,200 baik pada jenis ikan air tawar ataupun ikan laut. Perlakuan waktu fermentasi berpengaruh terhadap jumlah mikroorganisme pada lemea. Mikroorganisme yang terdapat pada lemea adalah bakteri asam laktat. 
Tabel 2. Hasil Analisis TPC Lemea (koloni/g)

\begin{tabular}{|c|c|c|}
\hline \multirow{2}{*}{$\begin{array}{c}\text { Waktu } \\
\text { Fermentasi } \\
(\text { Jam) }\end{array}$} & $\begin{array}{c}|c| \\
\text { Ikan Air Tawar } \\
\text { (Ikan Mujair) }\end{array}$ & $\begin{array}{c}\text { Ikan Laut } \\
\text { (Ikan Manyung) }\end{array}$ \\
\cline { 2 - 3 } & $1,200^{\mathrm{e}}$ & $1,200^{\mathrm{e}}$ \\
\hline $\mathbf{7 2}$ & $2,500^{\mathrm{c}}$ & $1,800^{\mathrm{d}}$ \\
\hline $\mathbf{1 2 0}$ & $2,900^{\mathrm{b}}$ & $4,700^{\mathrm{a}}$ \\
\hline
\end{tabular}

Ket : Angka yang diikuti oleh kode huruf yang berbeda menunjukkan adanya perbedaan yang nyata pada taraf signifikansi 5\%, (pada kolom yang sama)

Semakin lama waktu fermentasi maka semakin tinggi atau meningkat mikroorganisme untuk tumbuh. Hal tersebut dapat disebabkan oleh ikan yang terdapat dalam lemea. Menurut Nurhayani (2000), proses fermentasi akan menghasilkan enzim yang akan mendegradasi senyawa-senyawa komplek menjadi lebih sederhana dan mikroba juga akan mensintesis protein yang merupakan proses protein enrichment yaitu pengkayaan protein bahan.

Menurut SNI-01-2976-2006 untuk mutu mikrobiologi terasi dengan TPC per gram $1.10^{4}$ hingga $5.10^{4} \mathrm{Cfu} / \mathrm{gr}$ (Coloni Farming Unit Per Gram). Sedangkan pada hasil penelitian ini adalah berkisar antara 1,200 hingga 4,700 yang menunjukkan bahwa jumlah mikroba tersebut sudah memenuhi standar (SNI). Berdasarkan tabel 2 dapat diketahui TPC (Total Plat Count) lemea dengan perlakuan jenis ikan air tawar (ikan mujair) lebih rendah dibanding TPC dengan perlakuan ikan laut (ikan manyung). Hal ini disebabkan protein yang terkandung pada jenis ikan air tawar (ikan mujair) lebih rendah dibandingkan protein ikan laut (ikan manyung), dimana protein ikan air tawar (ikan mujair) sebesar 18,2 gram dan ikan laut (ikan manyung) sebesar 21,4 gram. Semakin tinggi protein yang terkadung dalam suatu bahan maka akan semakin meningkat pertumbuhan mikroorganisme untuk tumbuh. Proses fermentasi mikroba akan menghasilkan enzim yang akan mendegradasi senyawa-senyawa komplek menjadi lebih sederhana, dan mikroba juga akan mensintesis protein yang merupakan proses protein enrichment yaitu pengkayaan protein bahan (Nurhayani, 2000).

\section{Organoleptik Warna Sambal Lemea}

Hasil rerata analisis organoleptik warna lemea dengan perlakuan jenis ikan air tawar (ikan mujair) dan ikan laut (ikan 
manyung) dengan waktu fermentasi 72 jam, 120 jam dan 168 jam dapat dilihat pada tabel 3. Tabel 3 menjelaskan bahwa dari hasil analisis organoleptik terhadap warna sambal lemea menunjukkan ada perbedaan yang nyata pada taraf signifikan $0,5 \%$. Nilai rerata warna sambal lemea dengan pelakuan jenis ikan air tawar (ikan mujair) dan waktu fermentasi 72 jam , 120 jam dan 168 jam berkisar antara 2,45 (menarik) hingga 3,15 (netral). Nilai rerata warna sambal lemea dengan pelakuan jenis ikan laut (ikan manyung) dan waktu fermentasi 72 jam , 120 jam dan 168 jam berkisar antara 2,20 (menarik) hingga 3,30 (netral).

Warna sambal lemea yang paling disukai adalah sambal lemea dengan jenis ikan laut (manyung) dengan waktu fermentasi 168 jam. Hal ini disebabkan warna sambal lemea sangat menarik yaitu warna yang dihasilkan adalah merah terang, yang disebabkan warna dari sebagian dari bahan baku seperti cabai memiliki warna yang merah. Warna merah pada cabai merah berasal dari pigmen karotenoid yaitu kelompok pigmen yang berwarna kuning, orange, merah serta larut dalam minyak (Dutta, 2005).

Menurut Kartika (2001), warna makanan merupakan sifat bahan yang dianggap berasal dari penyebaran spektrum sinar dari bahan yang dipengaruhi oleh sinar pantul. Suatu bahan makanan yang dinilai bergizi dan enak tidak akan dimakan apabila tidak memiliki warna yang tidak sedap dipandang atau di pandang atau memberi kesan telah menyimpang dari warna yang seharusnya.

Tabel 3. Hasil Analisis Organoleptik Warna Sambal Lemea

\begin{tabular}{|c|c|c|}
\hline \multirow{2}{*}{$\begin{array}{c}\text { Waktu } \\
\text { (Jamentasi }\end{array}$} & \multicolumn{2}{|c|}{ Jenis Ikan } \\
\cline { 2 - 3 } & $\begin{array}{c}\text { Ikan Air Tawar } \\
\text { (Ikan Mujair) }\end{array}$ & $\begin{array}{c}\text { Ikan Laut } \\
\text { (Ikan Manyung) }\end{array}$ \\
\hline $\mathbf{7 2}$ & $3,15^{\mathrm{ab}}$ & $3,30^{\mathrm{a}}$ \\
\hline $\mathbf{1 2 0}$ & $2,55^{\mathrm{bc}}$ & $2,75^{\mathrm{abc}}$ \\
\hline $\mathbf{1 6 8}$ & $2,45^{\mathrm{bc}}$ & $2,20^{\mathrm{c}}$ \\
\hline
\end{tabular}

Keterangan : Angka yang diikuti oleh kode huruf yang berbeda menunjukkan adanya perbedaan yang nyata pada taraf signifikansi 5\%. Ket Skala : 1= sangat menarik; $2=$ menarik; $3=$ netral; $4=$ tidak menarik; $5=$ sangat tidak menarik 


\section{Organoleptik Rasa Sambal Lemea}

Hasil rerata analisis uji organoleptik aroma lemea dengan perlakuan jenis ikan air tawar (ikan mujair) dan ikan laut (ikan manyung) dengan waktu fermentasi 72 jam, 120 jam dan 168 jam dapat dilihat pada tabel 4 .

Tabel 4. menjelaskan bahwa dari hasil analisis uji organoleptik terhadap rasa sambal lemea menunjukkan ada perbedaan yang nyata pada taraf signifikan $0,5 \%$. Nilai rerata rasa sambal lemea dengan pelakuan jenis ikan air tawar (ikan mujair) dan waktu fermentasi 72 jam, 120 jam dan 168 jam berkisar antara 2,65 hingga 3,35 berada pada skala penilaian enak. Nilai rerata rasa sambal lemea dengan pelakuan jenis ikan laut (ikan manyung) dan waktu fermentasi 72 jam, 120 jam dan 168 jam berkisar antara 2,30 hingga 3,20 juga berada pada skala penilaian enak.
Rasa sambal lemea yang paling disukai adalah sambal lemea dengan jenis ikan laut (manyung) dengan waktu fermentasi 168 jam. Hal ini disebabkan rasa sambal lemea sangat enak yaitu rasa yang dihasilkan adalah rasa yang agak asam. Menurut Anonim (2012), rasa sambal lemea semakin asam dengan semakin lamanya fermentasi. Rasa asam terbentuk karena proses fermentasi yang menghasilkan asam-asam organik.

\section{Organoleptik Aroma Sambal Lemea}

Hasil rerata analisis uji organoleptik aroma lemea dengan perlakuan jenis ikan air tawar (ikan mujair) dan ikan laut (ikan manyung) dengan waktu fermentasi 72 jam, 120 jam dan 168 jam dapat dilihat pada tabel 5.

Tabel 4. Hasill Analisis Organoleptik Rasa Sambal Lemea

\begin{tabular}{|c|c|c|}
\hline \multirow{2}{*}{$\begin{array}{c}\text { Waktu } \\
\text { Fermentasi } \\
\text { (Jam) }\end{array}$} & $\begin{array}{c}|c| \\
\text { Ikan Air Tawar } \\
\text { (Ikan Mujair) }\end{array}$ & $\begin{array}{c}\text { Ikan Laut } \\
\text { (Ikan Manyung) }\end{array}$ \\
\cline { 2 - 3 } & $3,35^{\mathrm{a}}$ & $3,20^{\mathrm{ab}}$ \\
\hline $\mathbf{7 2}$ & $2,70^{\mathrm{abc}}$ & $2,80^{\mathrm{abc}}$ \\
\hline $\mathbf{1 6 8}$ & $2,65^{\mathrm{bc}}$ & $2,30^{\mathrm{c}}$ \\
\hline
\end{tabular}

Keterangan : Angka yang diikuti oleh kode huruf yang berbeda menunjukkan adanya perbedaan yang nyata pada taraf signifikansi $5 \%$. Ket Skala : $1=$ sangat enak; $2=$ enak; $3=$ netral; $4=$ tidak enak; $5=$ sangat tidak enak 
Tabel 5. Hasil Analisis Organoleptik Aroma Sambal Lemea

\begin{tabular}{|c|c|c|}
\hline \multirow{2}{*}{$\begin{array}{c}\text { Waktu } \\
\text { Fermentasi } \\
(\text { Jam) }\end{array}$} & $\begin{array}{c}|c| \\
\text { Ikan Air Tawar } \\
\text { (Ikan Mujair) }\end{array}$ & $\begin{array}{c}\text { Ikan Laut } \\
\text { (Ikan Manyung) }\end{array}$ \\
\cline { 2 - 3 } & $3,10^{\mathrm{a}}$ & $3,35^{\mathrm{a}}$ \\
\hline $\mathbf{1 2 0}$ & $3,05^{\mathrm{a}}$ & $2,95^{\mathrm{a}}$ \\
\hline $\mathbf{1 6 8}$ & $2,90^{\mathrm{a}}$ & $2,65^{\mathrm{a}}$ \\
\hline
\end{tabular}

Ket : Angka yang diikuti oleh kode huruf yang berbeda menunjukkan adanya perbedaan yang nyata pada taraf signifikansi $5 \%$. Ket Skala : $1=$ sangat harum; $2=$ harum; $3=$ netral; 4 $=$ tidak harum; 5 = sangat tidak harum

Tabel 5. menjelaskan bahwa dari hasil analisis uji organoleptik terhadap aroma sambal lemea menunjukkan tidak ada perbedaan yang nyata pada taraf signifikan $0,5 \%$. Nilai rerata rasa sambal lemea dengan pelakuan jenis ikan air tawar (ikan mujair) dan waktu fermentasi 72 jam, 120 jam dan 168 jam berkisar antara 2,90 hingga 3,10 berada pada skala penilaian harum. Nilai rerata warna sambal lemea dengan pelakuan jenis ikan laut (ikan manyung) dan waktu fermentasi 72 jam, 120 jam dan 168 jam berkisar antara 2,65 hingga 3,35 juga berada pada skala penilaian harum.

Aroma sambal lemea yang paling disukai adalah sambal lemea dengan jenis ikan laut (manyung) dengan waktu fermentasi 168 jam. Hal ini disebabkan aroma sambal lemea sangat khas, semakin lama penyimpanan dilakukan semakin menyengat juga aroma yang dihasilkan. Aroma lemea dipengaruhi juga oleh ikan yang dicampurkan pada lemea itu sendiri.
Menurut Marta (2007), selama pengolahan produk makanan, tidak hanya aroma alami dari produk makanan itu saja yang hilang tetapi juga terbentuk aroma baru akibat dari degradasi dalam medium asam yang menyebabkan khasnya aroma dari produk tersebut. Kemudian menurut Eckenfelder, et.al, (1998) mengatakan bahwa pengolahan pangan secara anaerob berpotensi menimbulkan bau.

\section{KESIMPULAN}

Analisis $\mathrm{pH}$ lemea tertinggi adalah $\mathrm{pH}$ yang terdapat pada perlakuan jenis ikan laut (ikan manyung) dengan waktu fermentasi 72 jam yaitu sebesar 7,566 Berdasarkan hasil analisis TPC tertinggi terdapat pada perlakuan jenis ikan laut (ikan manyung) dengan waktu fermentasi 72 jam yaitu sebesar 4,700. Hasil analisis uji sensoris terhadap warna sambal lemea paling di sukai adalah sambal lemea dengan jenis ikan laut (manyung) dengan waktu fermentasi 168 jam. Sedangkan 
rasa dan aroma sambal lemea yang paling disukai juga adalah sambal lemea dengan jenis ikan laut (manyung) dengan waktu fermentasi 168 jam.

\section{DAFTAR PUSTAKA}

Buckle, KA, dkk. 1995. Ilmu Pangan. Terjemahan Hari Purnomo dan Adiono. Press UI. Jakarta.

Badan Litbang. 2012. Pengawasan Obat dan Makanan. Bahan Tambahan Pangan. RI.Jakarta.

Dewi. 2012. Pemilihan Alat dan Lama Fermentasi Pada Proses Pembuatan Lemea Makanan Tradisional Suku Rejang. Skripsi fakultas pertanian. Jurusan Teknologi pertanian. Universitas Bengkulu. (Tidak dipublikasikan).

Eckenfelder, W.W., Patoczka, J.B., and Pulliam, G.W.(1988). Anaerobic Versus Aerobic Treatment In The USA.in: Anaerobic Digestion 1988, E.R.Hall and P.N.Hobson(eds.),Pergamon Press New York.

Desrosier, N.W. 1998. Teknologi Pengawetan Pangan. Universitas Indonesia (UI-Press). Jakarta.

Dutta.2005. Analisis Pengaruh Lama Fermentasi dan Konsentrasi Glukosa Terhadap Aktivitas Anti Bakteri, Malang. Skripsi elibrary.ub.ac.id.

Fardias. 1992. Mikrobiologi Pangan. PT. Gramedia Pustaka Utama. Jakarta.

Firansyah. 2012. Kajian Perubahan Mutu Lemea Selama Proses Penyimpanan dalam berbagai Jenis Bahan Pengemas. Skripsi fakultas pertanian. Jurusan Teknologi pertanian. Universitas Bengkulu. (Tidak dipublikasikan).

Hayati. 2009. MBahan Makanan Tambahan Pangan, Analisis Dan Aspek Kesehatan. Bumi Aksara. Jakarta.
Haryadi, P. 2006. Mutu dan Ingridien Pangan. Food Reviw Indonesia.

Kartika, Bambang. 2001. Petunjuk Evaluasi Produk Industri Hasil Pertanian. UGM. Yogyakarta.

Khopkar. 2003.Mikrobiologi Pangan. PT. Gramedia Pustaka Utama. Jakarta.

Mahmud, Mien. K dan Nils Arial Sulfianto.2009. Tabel Komposisisi Pangan Indonesia (TKPI). PT Elex Media Komputindo. Jakarta.

Nurhayani, Yantri. 2012. Karakteristik Sambal Lemea Makanan Khas Suku Rejang Dan Perubahan Kualitas Produk Pada Berbagai Suhu Penyimpanan. Skripsi Fakultas Pertanian. Jurusan Teknologi pertanian. Universitas Bengkulu. (Tidak dipublikasikan).

Permiashawai. 2007. Pengetahuan Lokal, Makanan Tradisional dan Ketahanan Pangan. Wikipedia Indonesia.

Saputra, Bopi. 2010. Studi Identifikasi Makanan Olahan Lokal Provinsi Bengkulu Berbahan Dasar Ikan. Skripsi fakultas pertanian. Jurusan Teknologi pertanian. Universitas Bengkulu. (Tidak dipublikasikan).

Sefti. 2015. Kajian Pembuatan dan Perubahan Kadar Air dan pH Saos Lemea. Skripsi Fakultas Pertanian. Jurusan Teknologi pertanian. Universitas Bengkulu. (Tidak dipublikasikan).

Suciati. 2012. Pengaruh Lama Perendaman Dan Fermentasi Terhadap Kandungan Hcn Pada Tempe Kacang Karo (Canovalia esiformis L). Skripsi Fakultas Pertanian. Jurusan Teknologi pertanian. Universitas Bengkulu. (Tidak dipublikasikan).

Surna, E.2011. Modifikasi Bahan Baku pada Pembuatan "Lemea" Makanan Tradisional Suku Rejang. Skripsi Fakultas Pertanian. Jurusan Teknologi Pertanian. Universitas Bengkulu. 
Susanti. 2011. Identifikasi Makanan Khas Provinsi Bengkulu Berbahan Dasar Ikan. Prosiding Semitra Bidang Ilmu-ilmu BKSPTN Wilayah Barat. Vol 2.

Sustrianti. E. 2011. Kajian Waktu Dan

Wadah Fermentasi Pada Proses
Pembuatan Lemea Makanan

Tradisional Suku Rejang. Skripsi

Fakultas Pertanian. Jurusan

Teknologi pertanian. Universitas Bengkulu. (Tidak dipublikasikan). 